Abstracta Iranica Iranica

Revue bibliographique pour le domaine irano-aryen

Volume 27 | 2006

Comptes rendus des publications de 2004

\title{
La science des lettres en terre d'Islam. Paris, Dervy, 2004, 148 p. [Esprit de lettre]
}

Ève Feuillebois-Piérunek

\section{(2) OpenEdition}

1 Journals

Édition électronique

URL : http://journals.openedition.org/abstractairanica/6271

DOI : 10.4000/abstractairanica.6271

ISSN : 1961-960X

\section{Éditeur :}

CNRS (UMR 7528 Mondes iraniens et indiens), Éditions de l'IFRI

\section{Édition imprimée}

Date de publication : 15 mai 2006

ISSN : 0240-8910

\section{Référence électronique}

Ève Feuillebois-Piérunek, "La science des lettres en terre d'Islam. Paris, Dervy, 2004, 148 p. [Esprit de lettre] », Abstracta Iranica [En ligne], Volume 27 | 2006, document 275, mis en ligne le 02 janvier 2007, consulté le 25 septembre 2020. URL : http://journals.openedition.org/abstractairanica/6271 ; DOI : https://doi.org/10.4000/abstractairanica.6271

Ce document a été généré automatiquement le 25 septembre 2020.

Tous droits réservés 


\title{
La science des lettres en terre d'Islam. Paris, Dervy, 2004, 148 p. [Esprit de lettre]
}

\author{
Ève Feuillebois-Piérunek
}

1 La science des lettres (al-simiya $)$ ou science de la transmutation de la parole, proche de l'alchimie (al-kimiyā), a longtemps été négligée bien qu'elle constitue une voie d'approche intéressante de la spiritualité islamique. Elle s'appuie sur la perception musulmane du Coran comme présence divine parmi les hommes, alors que l'univers entier est signe et Livre.

2 Les différents textes de ce volume proviennent de publications antérieures, issues de conférences, revues et remaniées à l'intention du grand public, ce qui explique leur caractère parfois assez superficiel. Après un rappel sur l'angélologie, en particulier le rapport entre les anges et le Verbe divin, l'A. présente brièvement les principes, les applications et quelques grands textes de la science des lettres.

Trois chapitres traitent successivement des rapports de la science des lettres avec le chiisme, la philosophie, et la magie, à travers l'analyse de textes représentatifs : la doctrine du gnostique Mugīira ibn Sa îid $\left(8^{\mathrm{e}} \mathrm{s}\right.$.) telle qu'elle est exprimée dans la littérature hérésiologique, certaines des Épîtres des IḨwān al-Ṣafā' consacrées à la science du langage ( $\left(10^{\mathrm{e}} \mathrm{s}\right.$.), la Risāla Nayrūziyya d'Avicenne $\left(11^{\mathrm{e}} \mathrm{s}.\right)$, le traité de magie Šams al-Ma'ārif d'al-Būnī (13 $13^{\mathrm{e}} \mathrm{s}$.). Un autre chapitre est consacré aux spéculations d'Ibn 'Arabī sur le sens des lettres et des mots. 
INDEX

Thèmes : 8. Soufisme

nompropre Avicenne, Ibn 'Arabi

\section{AUTEURS}

ÈVE FEUILLEBOIS-PIÉRUNEK

Sorbonne Nouvelle - Paris III 